\title{
Connectivity, energy, and transportation in Uzbekistan's strategy vis-à-vis Russia, China, South Korea, and Japan
}

\author{
Timur Dadabaev $^{1}$ (D) Nigora Djalilova ${ }^{1}$
}

Received: 9 April 2020 / Revised: 14 July 2020 / Accepted: 8 September 2020 /

Published online: 23 September 2020

C) Springer-Verlag GmbH Germany, part of Springer Nature 2020

\begin{abstract}
This paper focuses on the articulated intentions andregistered projects of emerging developmental government in Uzbekistanvis-a-vis Russia, China, South Korea and Japan in the areas of Energy andTransport Infrastructure Development. By thematically analyzing the cooperationroadmaps for 2017-2019, this paper offers insights into how Uzbekistaninternalizes energy and infrastructure-related projects with these countries inits re-opening to the international community in post-Karimov era. This paperclaims that Uzbekistan looks beyond the connectivity rhetoric in its foreignpartners' interest in energy and transportation and seeks to capitalize on therelated projects to position itself as an industrial and transportation hub forother CA countries and Afghanistan. In addition, for Uzbekistan, theinfrastructure and energy-related initiatives are part of its de-colonizationagenda aiming to shift its economy from being resource-based to being based onthe export of value-added products.
\end{abstract}

\section{Introduction}

The existent literature on the interactions and infrastructure development strategies of Central Asian states, including Uzbekistan, narrates their policies in relation to major international partners from two main perspectives. This first one suggests that infrastructure and energy development strategies of China, Russia, and other states aim to exploit this region's resources. In such treatment, CA regional governmental strategies are presented as reactive and only passively responding to the "great game" intentions of bigger players (Swanstrom 2005; Dugin 2007; Chen and Fazilov 2018; Freeman

Timur Dadabaev

dadabaev.timur.gm@u.tsukuba.ac.jp

Nigora Djalilova

d.nigora@gmail.com

1 Faculty of Social Sciences and Humanities, University of Tsukuba, Tsukuba, Japan 
2018). The second position taken in some other studies suggests that CA governmental bureaucracies play their own rules (Cooley 2012), balancing these powers (Pikalov 2014) and utilizing local networks and dynamics (Megoran and Sharipova 2013) in dealing with foreign pressures. However, useful these narrations may be, they do not explain the way and manner in which these smaller regional governments, exemplified by Uzbekistan in this paper, manage to successfully implement infrastructure and energy-related projects which are seemingly irreconcilable in terms of their main participants and goals. The accounts mentioned above provide the narrative from the stance of foreign partners of CA states overlooking the logic of regional states. This is the gap that this paper aims to fill in by detailing on the energy and transport infrastructure development strategies of Uzbekistan with its main international partners.

This paper raises the following questions: What are the impacts of infrastructurerelated projects with Russia, China, South Korea, and Japan on Uzbekistan's economic development? How do these reflect on the changing nature of the economic development model that Uzbekistan aspires to implement?

This paper focuses on the articulated investment intentions and registered projects in the area of energy and transport infrastructure development with Russia China, South Korea, and Japan. Methodologically, this paper analyzes economic cooperation roadmaps - a set of project outlines drafted by Uzbekistan's government with the aforementioned countries for the period of 2016-2019. This paper treats the roadmaps as Uzbek governmental narrative of what it prioritizes in cooperation schemes with the states above. These cooperation roadmaps need to be treated as a type of discourse, which is subject to change depending on the circumstance of the participating countries, available funding, and change of the motivations of other actors (COVID-19, economic and financial crises, etc.) (for details see Dadabaev 2018b, 2019a). In this sense, this paper limits its coverage to the thematic analysis of the roadmaps, while leaving the coverage of the implementation and the degree of success or effectiveness of the projects mentioned in the roadmaps for future inquiry, as many of these projects are long-term ones and are currently in various stages of development. By thematically analyzing the roadmaps mentioned above, this paper offers insights into how Uzbekistan internalizes energy and infrastructure-related projects with these countries and explores the related economic and strategic impacts for Uzbekistan and Central Asia (CA) in its opening to the international community after the period of Karimov dictatorship. The energy and transportation infrastructure blueprints are chosen because of them being the most attractive to foreign partners and the most important sectors for Uzbek economic reforms.

\section{From a state-controlled economy towards an infrastructural development state in Uzbekistan}

There is a variety of studies in regard to the format of economic governance in postsocialist era (Lane 2005, 2007; Bolesta 2019). According to these, many post-socialist states, including Uzbekistan, were presented with the choice of drastic liberalization of economy called "shock therapy" (Popov 2007) or some variation of developmental state (see Johnson 1982; for this model in CA, see Stark and Ahrens 2012). Uzbekistan opted to preserve the active agency of the state and aspired to shape its investment 
policy through governmental interventions (Spechler 2000: 295-303; Fazendeiro 2015, 2017, 2018). Infrastructure development has been one of the most important policy aspects (see Fazendeiro 2015). In fact, immediately after the collapse of the Soviet Union and Uzbekistan's independence, President Karimov attempted to re-invigorate the notion of the ancient Silk Road and construct the railroad from Uzbekistan to China (Karimov 1992). Karimov's government proposed this aim in its cooperation agenda between the governments of China and Uzbekistan in 1992 during the visit of the thenForeign Minister of China Qian Qichen to Uzbekistan. Later, in 1994, Karimov unsuccessfully attempted to encourage the construction of a direct railway from Uzbekistan to China through Kyrgyzstan during Prime Minister Li Pen's visit to Uzbekistan (Khodzhaev 2007, p. 103). The aims that Karimov had in mind were related less to the notion of connecting Chinese markets with European consumers and more to the developmental agenda of Uzbekistan (Spechler and Spechler 2010: 159-170). On the one hand, Uzbekistan's transportation and energy infrastructure have been over-reliant on Russian networks for both the export of Uzbek goods and resources and transportation services. In this sense, cooperation with China represented a de-colonization drive towards China-focused infrastructure to compensate for overdependency on Russia and offer more trade routes for Uzbekistan (Dadabaev 2018a, 2019b). On the other hand, Uzbekistan sees China as a resource for its developmental agenda in which the government plays a significant role in the otherwise liberalized market economy (for relevance and critique, see Ahrens and Stark 2014: 95-110).

To a great extent, Uzbekistan's proposal to China about the potential for revival of the Silk Road in the early 1990s reflected the Uzbek government's attitude towards developing its own economic model (for comparative analysis of East and Central Asian models, see Stark 2012; Thompson 2017). While this model has often been criticized for being based on "self-reliance" and isolationism (see Fazendeiro 2015, 2017), its main principles resonate with the Chinese economic model, also referred to as China's "Singapore" model (Thompson 2017) or "post-socialist development state" (Bolesta 2019). The five main principles of Karimov's economic reforms referred to the priority of the economy over politics (ideology), the role of the state as the main actor (reformer) in economic activity, the establishment of transparency and rule of law, a social policy orientation, and, finally, a stage-by-stage transition towards a market economy (Karimov 1992). The idea behind this model, which was implemented in Uzbekistan from 1991 to 2016, was that a strong executive power can ensure the political stability needed for attracting investments and developing the economy. This model was expected to eventually lead to the formation of a middle class and sustainable economic growth (for self-legitimization of Uzbek model, see Ahrens et al. 2016: 47-71). However, over the years of Karimov's dictatorial rule, it became obvious that government often, if not consistently, abused its executive powers under the pretext of external threats and terrorist menaces (for the problem legitimization and economic model of Karimov era, see Ahrens et al. 2016: 47-71). Such abuses led to corruption throughout all spheres of public life in the country and major retreat in economic indicators for the general public and the state.

President Mirziyoyev's (2016 onward) rhetoric, articulated on various occasions after his election to the presidency, demonstrates that ideally, he favors the model where the government plays only regulatory role and does not dictate what industries should do (for the analysis of Mirziyoyev's policies, see Dadabaev 2018e, 2019c, 2020b; for the development of various developmental state models, see Johnson 1999: 
32-60;). For instance, referring to the total control of 33 state bodies over the licensing of economic activities in hundreds of areas, Mirziyoyev famously exclaimed, "Who needs this? Where is the guarantee that there is no corruption there?" (Daryo 2017). The economic model he prefers is often referred to as the "rational market" model government behavior, where actors can act freely within the boundaries of legal norms (for specificities of state-business relations in CA, see Libman 2008; President's Office 2019, 2020). ${ }^{1}$

However, this model remains the distant goal of the government given the country's low economic development and slow rate of industrialization. For the present, the Uzbek government adheres to the "developmental state" model, in which the governments shape industrial policy and spearhead infrastructure development (Bolesta 2019: 3-8; Also Thompson 2017). The infrastructure development and the usage of connectivity projects in Eurasia in recent years by the Uzbek government can be considered "plan-rational" in nature.

For the Uzbek government, the major goal of developing energy and transportation infrastructure is to enhance the national industrial policy and serve the export-oriented policy (see TCA 2017).

In this approach, the general decisions that shape industrial- and infrastructurerelated policies are made by several major ministries, such as the Ministry of Investment and Foreign Trade, Ministry of Economy and Industry, Ministry of Transport, and Ministry of Finance. Sector-related decisions are also influenced by the Ministry of Agricultural Resources, Ministry of Water Resources, and Ministry of Energy. The Ministry of Foreign Affairs is called upon to facilitate the work of these ministries with their foreign counterparts and to provide the first point of contact for foreign counterparts (UZ.A 2018) (see Fig. 1).

\section{Normative basis of Uzbekistan's infrastructure development strategy}

There are five main documents that describe the Uzbek government's stance towards infrastructure development in the post-Karimov era. The most important document that signals the Mirziyoyev administration's goals, the "Action Strategy on Five Priority Directions for the Development of the Republic of Uzbekistan 2017-2021", serves as a blueprint for the goals to be achieved in the period of 2017-2021 (UZINFOCOM Action Strategy; Strategy Center 2017). While the document is very general in its wording, it designates several areas, such as governance and transparency (by introducing e-governance), for improvement at all levels and singles out transport, energy, industry, and renewable resource development for special attention as the targeted sectors for investment and technological improvement (for these sectors, see Djalilova and Esteban 2018).

The intensified efforts to develop these sectors demonstrate that the focus of the Karimov government in the immediate post-independence years on cotton production

\footnotetext{
${ }^{1}$ For instance, the Ministry of Construction manages 35 areas of licensing, the Ministry of Development and Information Technologies and Communications oversees 34 areas of licensing, the State Inspection Agency on Controls in Education oversees 438 areas of licensing, and the State Taxation Committee oversees 80 licensing areas.
} 


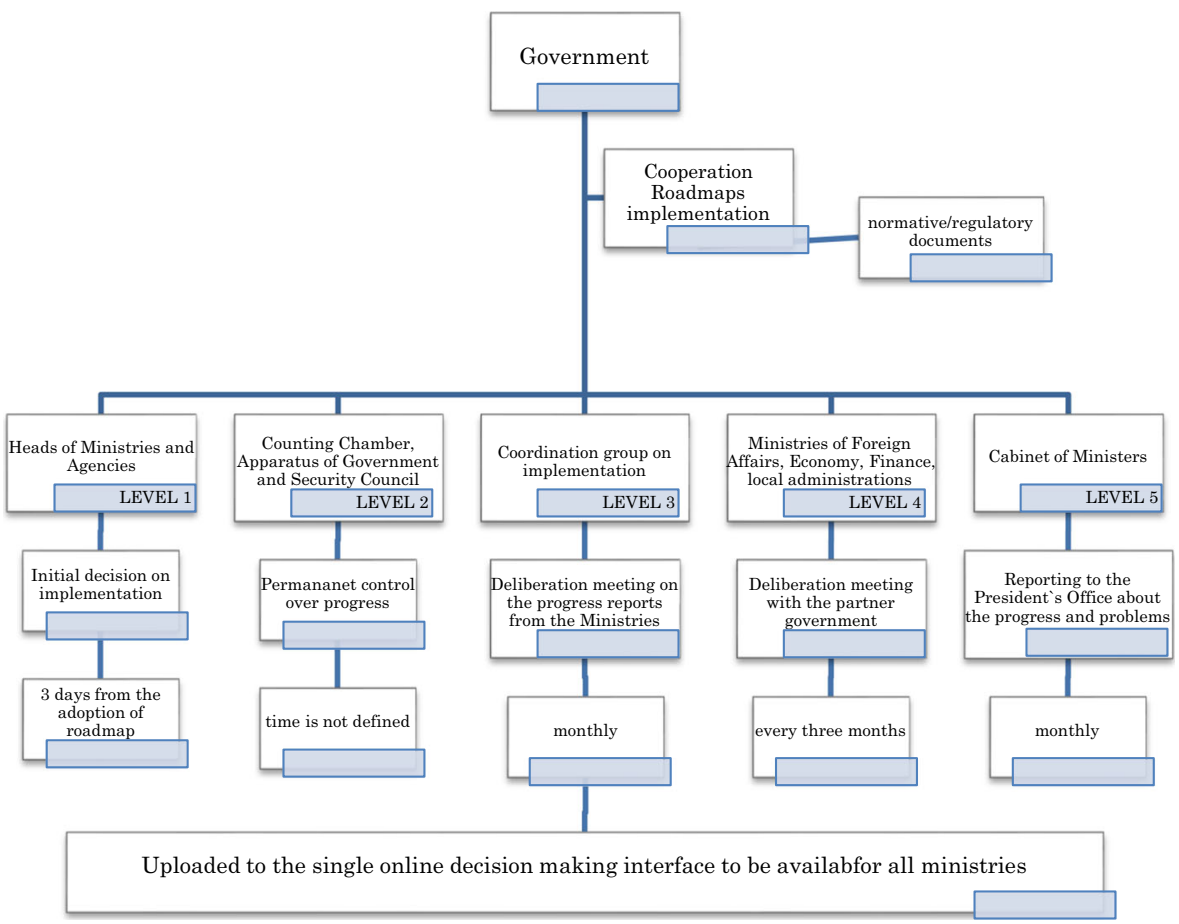

Fig. 1 Implementation of the roadmaps of cooperation. Source: compiled by authors

and exports of natural gas did not spill over into industrial development and diversification of Uzbekistan's economy due to heavy governmental controls. The postKarimov government of Uzbekistan aims to achieve these goals through liberalizing its economy and decreasing the presence of the state, which is in stark contrast to Karimov's economic policy. However, the intensification of private entrepreneurship would undoubtedly cause an increase in energy and other resource consumption by economic actors, requiring investments into modernizing the transportation and energy generation infrastructure.

The "Strategy of the Investment Policy of the Republic of Uzbekistan until 2025" (hereinafter, the investment strategy) provides the government's design for improved conditions for investments. There are three goals of this strategy which are namely investor-friendly legal and policy climate creation (with anti-corruption measures included), domestic investment mobilization, and FDI attraction.

On par with international financing, Mirziyoyev aims to mobilize domestic resources into the economy by offering potential investors in priority sectors the opportunity to legalize their resources. As shown in Table 1, the current sources of domestic investment are limited, and there is potential in seeking a larger share.

In terms of FDI, the investment strategy offers incentives and simplifies the documentation processes. Stipulating the investments for particular sectors, the following three documents indicate the governmental stance regarding investments in transport, sustainable energy resources, and water resource development. 
Table 1 Structure of investments in fixed assets by sources of financing (as a percentage of the total)

\begin{tabular}{|c|c|c|c|c|c|}
\hline & \multirow{2}{*}{$\begin{array}{l}\text { Own means } \\
\text { of enterprises } \\
\text { and } \\
\text { population }\end{array}$} & \multirow{2}{*}{$\begin{array}{l}\text { Involved } \\
\text { funds }\end{array}$} & \multicolumn{3}{|c|}{ Funds from } \\
\hline & & & \multirow[t]{2}{*}{$\begin{array}{l}\text { State } \\
\text { budget }\end{array}$} & \multirow[t]{2}{*}{$\begin{array}{l}\text { Loans from } \\
\text { banks and other } \\
\text { borrowed funds }\end{array}$} & \multirow[t]{2}{*}{$\begin{array}{l}\text { Foreign } \\
\text { investments } \\
\text { and credits }\end{array}$} \\
\hline & \multicolumn{2}{|c|}{ January-September 2019} & & & \\
\hline Republic of Uzbekistan & 31.4 & 68.6 & 8.5 & 15.7 & 39.2 \\
\hline Republic of Karakalpakstan & 34.7 & 65.3 & 13.6 & 7.6 & 39 \\
\hline \multicolumn{6}{|l|}{ Regions } \\
\hline Andijan & 35.5 & 64.5 & 9.6 & 16.7 & 37.4 \\
\hline Bukhara & 28.8 & 71.2 & 7.9 & 13.7 & 48.4 \\
\hline Jizzakh & 20.2 & 79.8 & 13 & 11.4 & 53.6 \\
\hline Kashkadarya & 26.1 & 73.9 & 4.6 & 4.1 & 64.5 \\
\hline Navoi & 15.2 & 84.8 & 2.3 & 22.4 & 37.9 \\
\hline Namangan & 34.3 & 65.7 & 5.5 & 11.6 & 37.1 \\
\hline Samarkand & 40.4 & 59.6 & 11.8 & 23.4 & 22.5 \\
\hline Surkhandarya & 32.4 & 67.6 & 9.5 & 20.6 & 35.5 \\
\hline Syrdarya & 22.7 & 77.3 & 11.4 & 18.9 & 44.9 \\
\hline Tashkent & 34.3 & 65.7 & 14.1 & 14.8 & 28.5 \\
\hline Fergana & 38.8 & 61.2 & 7.3 & 13.2 & 39.9 \\
\hline Khorezm & 38.1 & 61.9 & 11.3 & 18.3 & 25.5 \\
\hline Tashkent city & 36.4 & 63.6 & 6.9 & 20.2 & 34 \\
\hline
\end{tabular}

Source: National Statistics Committee, https://stat.uz/en/181-ofytsyalnaia-statystyka-en/6375-investments

As an example, the "Strategy for the Development of the Transport System of the Republic of Uzbekistan until 2035" sets the standards and goals for improving transport services to the general public, which have suffered decay and underinvestment in the past two decades. In addition, this document aims to address the unbalanced development of the national network of transportation and extend services to the residents of remote areas of the country. A second area the document highlights for modernization is the creation of transportation corridors to integrate Uzbek transportation networks with regional networks for human travel and goods transport. In addition, the document states the government's aim to modernize the sector by attracting previously unavailable technologies.

Furthermore, the "Strategy of the Republic of Uzbekistan for the Transition to a Green Economy" details the incentives for investors in energy-related facilities to increase the efficiency of the existing infrastructure, which was mostly constructed and developed in the Soviet era and presents outdated technology.

Additionally, the "Concept of Development of the Hydropower Industry of the Republic of Uzbekistan for 2020-2024", adopted in 2019, provides a basis for investments in the modernization of hydropower facilities and the construction of new plants. The governmental blueprint implies investments into small-scale hydropower generation dams and facilities because these are regarded by Uzbek hydro-professionals as providing more sustainable and less expensive energy generation than large-scale 
Table 2 Foreign trade turnover of the Republic of Uzbekistan, January-June 2019

\begin{tabular}{|c|c|c|c|c|c|c|}
\hline \multicolumn{2}{|c|}{ (January-June 2019) } & \multirow{2}{*}{$\begin{array}{l}\text { Million USD } \\
2019\end{array}$} & \multicolumn{2}{|c|}{ Growth rate, $\%$} & \multicolumn{2}{|c|}{ Position } \\
\hline Countries & 2018 & & 2018 & 2019 & 2018 & 2019 \\
\hline China & 1506,4 & 2296,4 & 128,7 & 152,4 & 2 & 1 \\
\hline Russia & 1812,1 & 1838,7 & 144,1 & 101,5 & 1 & 2 \\
\hline South Korea & 717,9 & 1299,2 & 138,9 & 181,0 & 4 & 3 \\
\hline Kazakhstan & 736,2 & 1001,5 & 157,3 & 136,0 & 3 & 4 \\
\hline Turkey & 495,0 & 615,9 & 156,3 & 124,4 & 5 & 5 \\
\hline Germany & 313,1 & 426,0 & 100,6 & 136,1 & 6 & 6 \\
\hline USA & 242,1 & 295,7 & 240,4 & 122,1 & 7 & 7 \\
\hline Turkmenistan & 70,6 & 218,5 & 103,2 & $3,1 \mathrm{p}$ & 16 & 8 \\
\hline Latvia & 206,3 & 195,1 & 184,5 & 94,6 & 8 & 9 \\
\hline Lithuania & 123,3 & 191,8 & 81,7 & 155,5 & 11 & 10 \\
\hline Belarus & 188,9 & 165,8 & $4,7 \mathrm{p}$ & 87,8 & 9 & 11 \\
\hline India & 120,8 & 155,1 & 82,1 & 128,4 & 12 & 12 \\
\hline Japan & 85,2 & 152,8 & 155,9 & 179,4 & 14 & 13 \\
\hline Italy & 110,1 & 136,6 & 156,8 & 124,1 & 13 & 14 \\
\hline Ukraine & 157,4 & 131,7 & 188,6 & 83,7 & 10 & 15 \\
\hline Iran & 41,2 & 94,3 & 174,8 & $2,3 \mathrm{p}$ & 23 & 16 \\
\hline Singapore & 6,7 & 87,5 & 144,5 & $13,0 \mathrm{p}$ & 47 & 17 \\
\hline Brazil & 7,4 & 73,5 & 3,7 & 9,9 p. & 43 & 18 \\
\hline Switzerland & 74,6 & 69,5 & 96,3 & 93,2 & 15 & 19 \\
\hline Kyrgyzstan & 59,4 & 67,8 & $2,2 \mathrm{p}$ & 114,2 & 19 & 20 \\
\hline
\end{tabular}

Source: The State Committee of the Republic of Uzbekistan on National Statistics

structures. The above measures regarding investments in renewable energy resources support the notion that solar, hydro, and atomic energy resources constitute the backbone of the country's economic industrialization.

Based on these normative documents, Uzbekistan negotiated and drafted roadmaps with Russia, China, South Korea, and Japan to outline cooperative projects targeting infrastructure development in several areas. This paper focuses on two particular areas, energy, and transportation infrastructure, as described below.

\section{Geography of the energy and transportation infrastructure}

Uzbekistan's choice of Russia, China, South Korea, and Japan as the primary initiators of energy and transportation infrastructure projects was not random, as can be seen from Table 2 below. According to recent estimates, a large portion (55.6\%) of FDI into Uzbekistan comes from Russia, with China accounting for $15 \%$, followed by Japan (6.6\%), the Netherlands (4.3\%), and the Islamic Development Bank (4.2\%) (OECD 2019 , p. 236). Along with these countries, South Korea is one of the top trading partners, providing Uzbekistan with machinery, technology, and skill training. Japan, 
Table 3 Structure of export of the Republic of Uzbekistan to China and Russia

\begin{tabular}{|c|c|c|c|c|}
\hline & \multicolumn{2}{|l|}{ China } & \multicolumn{2}{|l|}{ Russia } \\
\hline & 2018 & 2019 & 2018 & 2019 \\
\hline Total export & 1216,9 & 1599,2 & 947,7 & 1145,9 \\
\hline Cotton & 51,1 & 141,5 & 2,6 & 0,4 \\
\hline Foodstuffs & 29,4 & 30,4 & 80,3 & 97,9 \\
\hline Chemical products & 83 & 83,6 & 87,1 & 88,0 \\
\hline Energy and oil products & 471,5 & 704,1 & 219,9 & 368,4 \\
\hline Ferrous metals and products from them & 1,8 & 0,3 & 2,6 & 1,3 \\
\hline Nonferrous metals and related products & 30,8 & 52,4 & 17,1 & 48,5 \\
\hline Machinery and equipment, including parts & 2,1 & 2,0 & 35,7 & 35,3 \\
\hline Textiles and textile products & 156,0 & 211,8 & 279,5 & 300,3 \\
\hline
\end{tabular}

Source: The State Committee of the Republic of Uzbekistan on National Statistics

on the other hand, has been the largest provider of ODA and the most active partner in the rehabilitation of energy and transportation infrastructure over the years since independence. As demonstrated below, these countries also feature prominently among the trade partners of Uzbekistan in recent years.

Russia (1864) and China (1690) top the list of countries establishing companies backed with foreign capital, with China (38) establishing such companies at a rate exceeding that of Russia (36) as of January 2020. The third is Turkey (1306), which established 35 companies in January 2020 alone (The State Committee of the Republic of Uzbekistan on National Statistics 2020). As demonstrated below, the structure of Uzbekistan's exports to its major trade partners, Russia and China, mainly comprises cotton fiber, foodstuffs, natural and mineral resources, and textile products. The table below also demonstrates that the volume of exports to China now rivals and in some instances exceeds the volumes exported to Russia, symbolizing Uzbekistan's posture towards China. The figures in the Table 3 also demonstrate that despite the decolonizing agenda of the first President of Uzbekistan Karimov, Russia's position in terms of the export of goods and services remains very solid. China's economic rise and pivot towards CA has not necessarily challenged Russia's economic importance in Uzbekistan. In addition, the data below do not reflect the export of excess labor from Uzbekistan to Russia, which constitutes a large portion of Uzbek revenues.

Mirziyoyev's rise to power led to major economic reforms that aimed to increase the speed of industrialization and diversify production and that thus influenced Uzbekistan's import structure. To meet these aims, machinery and equipment became among the most important categories of imports. China $(31.1 \%)$ leads in terms of machinery and equipment imports, followed by South Korea (18.4\%), Russia (7.8\%), Turkey (7\%), and Germany (6.6\%) as is seen in Fig. 2.

According to OECD estimates, Uzbekistan spent USD 70.1 billion on various infrastructure projects between 2000 and 2018. The large majority (64\% or USD 37.2 billion) of these are energy projects in the oil and gas industry (45\%), electricity generation $(40 \%)$, oil and gas pipeline construction $(9 \%)$, and electric power 
Major partner countries exporting machinery and equipment

to the Republic of Uzbekistan

(January-June 2019)

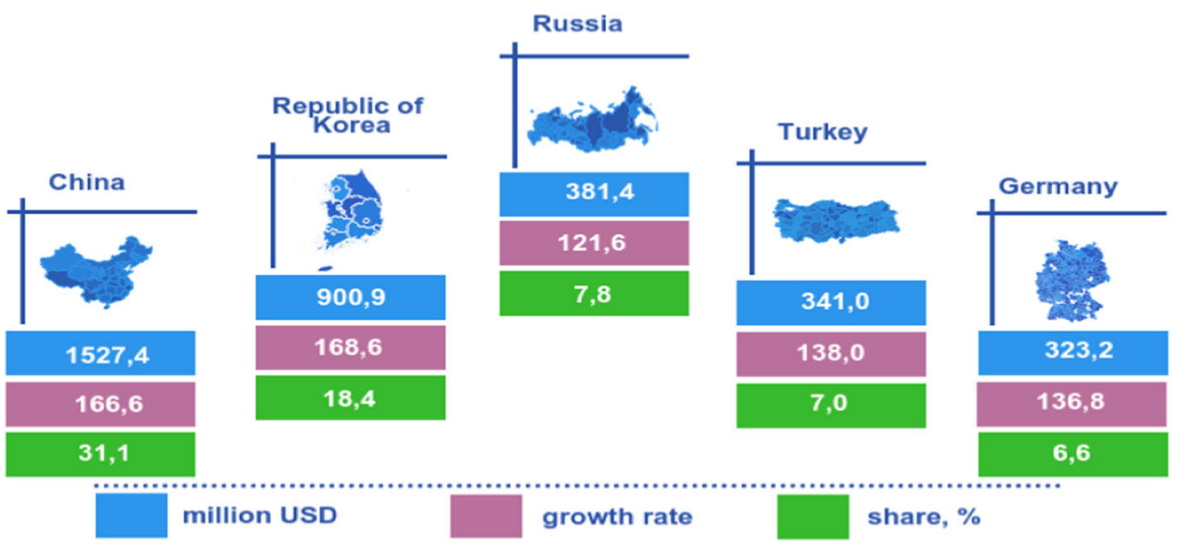

Fig. 2 Major partner countries exporting machinery and equipment to the Republic of Uzbekistan, JanuaryJune 2019. Source: The State Committee of the Republic of Uzbekistan on National Statistics

transmission and distribution (6\%). In addition to the energy infrastructure mentioned above, other infrastructure-related investments include manufacturing (23\%), transport (13\%), and water supply and sanitation (4\%) (OECD 2019).

In terms of transportation infrastructure, Uzbekistan utilizes 7 main transportation corridors to transport goods and services: the Baltic corridor, ${ }^{2}$ EU corridor, ${ }^{3}$ Ukrainebound corridor, ${ }^{4}$ TRACECA corridor, ${ }^{5}$ Persian Gulf corridor, ${ }^{6}$ (potential) Afghan corridor, ${ }^{7}$ and two Chinese corridors, one going through Kazakh-China border (Dostyk/Alashankou) and the other going through Kyrgyzstan towards the East China and South China Seas. Despite these transportation corridors, experts point out that for various reasons (such as road quality and poor connections), Uzbekistan ranks 99th out of 160 countries, with an overall score of 2.58 (out of 5) in the logistics performance index, as can be seen in Table 5. For a comparative perspective, Kazakhstan ranks 71st (2.81), the Kyrgyz Republic ranks 108th (2.55), Turkmenistan ranks 126th (2.41), and Tajikistan ranks 134th (2.34) (see Table 4).

These transportation deficiencies impact Uzbekistan's economy not only by slowing the shipment of Uzbek goods but also by decreasing the country's overall attractiveness. To compensate for them, Uzbekistan seeks international partnerships with various countries. These corridors show that Russia and China are the main transit points in Uzbekistan's transportation infrastructure, with a few alternatives presented by the Afghan and Caucasian corridors.

\footnotetext{
$\overline{2}$ Transiting through Kazakhstan and Russia towards Klaipeda, Riga, Liepaja, Ventspils, and Tallinn

3 Transiting through Belarus and Ukraine (transit through Kazakhstan and Russia)- border checkpoints Chop (Ukraine) and Brest (Belarus)

${ }^{4}$ Towards the Ukrainian port of Iljichyovsk, transiting through Kazakhstan and Russia and with access to the Black Sea

${ }^{5}$ Transiting through Turkmenistan, Kazakhstan, and Azerbaijan, with access to the Black Sea

${ }^{6}$ Towards the Iranian port of Bandar Abbas, transiting through Turkmenistan

${ }^{7}$ Transiting through Afghanistan to Iranian and Pakistani ports of Bandar Abbas, Chakhbahar (IRP)
} 
Table 4 World Bank logistics performance index for Uzbekistan in 2018

Generated from https://pi. worldbank.org/international/ scorecard/radar/254/C/UZB/ 2018\#chartarea

\begin{tabular}{ll}
\hline Uzbekistan year & 2018 \\
\hline LPI rank & 99 \\
LPI score & 2.58 \\
Customs & 140 \\
Customs2 & 2.1 \\
Infrastructure & 77 \\
Infrastructure3 & 2.57 \\
International shipments & 120 \\
International shipments4 & 2.42 \\
Logistics competence & 88 \\
Logistics competence5 & 2.59 \\
Tracking and tracing & 90 \\
Tracking and tracing6 & 2.71 \\
Timeliness & 91 \\
Timeliness7 & 3.09 \\
\hline
\end{tabular}

In this sense, Uzbekistan's focus on cooperation with Russia, China, South Korea, and Japan is a natural choice in light of their contribution of FDI into the Uzbek economy and its energy and transportation infrastructure, as described above. Typically, Uzbekistan drafts the roadmaps in the bilateral cooperation with its international partners which is a relatively new practice. The predecessors of roadmaps were drafted under the first president of Uzbekistan in the form of lists of tasks and projects to be conducted on a bilateral basis. However, with the rise of Mirziyoyev to power in 2016, the concept of roadmaps of cooperation became the common blueprint outlining the projects, budgets, sources of financing, and responsible/main actors in a very detailed manner. The Uzbek government drafts outlines of the projects and ensures their implementation by instituting the tools of control, as described in the first section of this paper. These agreements are signed during presidential visits to Russia, China, South Korea, and Japan and are updated on similar occasions.

This paper builds on the roadmaps made with Russia based on agreements made during the visit of the President of Uzbekistan to Russia on October 18-19, 2018, with China during the second international One Belt One Road forum in Beijing on April 24-27, 2019, with South Korea during the visit of the President of Republic of Korea Moon Jae-in to Uzbekistan on April 29, 2019, and with Japan during the visit of the President of Uzbekistan to Japan on December 17-20, 2019.

\section{Framework agreements with Russia, China, South Korea, and Japan regarding infrastructure and investments}

Each of the roadmaps is composed of several appendixes to the decree of the President of Uzbekistan. Issuing decrees and attaching the agreements between the parties has an important legal meaning for Uzbekistan because it ensures that the agreements between Uzbekistan and its partners are placed within its legal framework. 
The roadmaps are rather diverse and depend on the shared perspectives of the partners of Uzbekistan. For instance, the roadmap with Russia based on the agreements made during the visit of the President of Uzbekistan to Russia on October 18-19, 2018, consists of hundreds of documents and contracts in a number of diverse fields. Structurally, these projects are grouped into various appendixes classified according to the nature of the documents. For instance, appendix 3 consists of 85 investment projects, 10 projects in the fields of energy and resource management, 8 projects in the field of infrastructure development, and multiple contracts and trade agreements. Appendix 4 consists of the projects focusing on investments in areas other than energy, transportation, and resources. These projects, 91 in total, mostly concern the fields of agriculture, education, and humanitarian cooperation. The same appendix includes more than 400 trade contracts concluded by various state and nonstate enterprises. These contracts are included in the roadmaps because they relate to the developmental role of the Uzbek government, which again illustrates the government's active engagement in developmental rather than regulatory functions. Finally, appendix 5 consists of 73 major intergovernmental framework agreements that are of political and policyrelated nature. These are not meant to produce immediate economic impact but rather focus on preparing the political environment for cooperation.

The roadmaps with China are based on the cooperation agreements made during the visit of the President of Uzbekistan to the second international One Belt One Road forum in Beijing on April 24-27, 2019 (Decree of the President of Uzbekistan 2017). These roadmaps do not present comprehensive coverage but focus specifically on the goals to be achieved and budgets to be allocated. In this sense, they demonstrate the economic focus of bilateral cooperation for both China and Uzbekistan, while in the case of Russian-Uzbek cooperation, humanitarian and cultural components are also present, illustrating the common Soviet past and the cultural connections between the two states. The Chinese roadmaps consist of 14 documents devoted to establishing a common understanding of the need for cooperation, 7 documents developing political cooperation, 21 documents outlining investment in the fields of energy and transportation, 4 agreements regarding the military and security, and 3 humanitarian projects.

The Japanese roadmaps are based on the documents singed during the visit of the President of Uzbekistan to Japan on December 17-20, 2019, and include the presidential decree of cooperation between Uzbekistan and Japan. There are 10 political/ framework agreements, 17 trade/economic cooperation documents, 27 educationrelated documents, and 5 inter-regional documents in appendix 1 of the roadmaps. Appendix 2 is more relevant to the needs of the Uzbek economy and consists of 15 intergovernmental agreements and 48 investment-related agreements (Islamov 2019: 80-82). One feature that significantly differentiates the roadmaps of cooperation between Uzbekistan and Japan from the roadmaps with Russia and China is the part regarding the main actors on the Japanese side, which are mainly governmental institutions, the Japan International Cooperation Agency (JICA), and very few private enterprises. This to a great extent reflects the challenges that Uzbekistan faces in positioning itself as an important country for Japanese private investments.

Finally, the roadmaps with South Korea are based on the agreements achieved during the visit of President of the Republic of Korea Moon Jae-in to Uzbekistan on April 29, 2019, and consist of 17 intergovernmental agreements, 22 framework agreements of cooperation between various state agencies, 21 agreements related to investments and 
technology transfer, and 11 agreements of humanitarian nature. In terms of investments, the roadmaps define 26 main projects in the fields of energy resource development and processing. The field of manufacturing, which is not covered in this paper but remains one of the most important areas of cooperation between Uzbekistan and South Korea, receives a wide coverage, with 43 projects established and included in the roadmaps. The package of investment documents indicates an overall amount of approximately USD 12 billion to be invested. In contrast to the Japanese projects, South Korean projects heavily build on the presence of Korean businesses in Uzbekistan and, to a great extent, aim to maintain and support that presence in the country.

The projects listed above are multi-year ones planned to be implemented over the long-term period. In this sense, the evaluation of their efficiency and impact requires longer period. To that end, this paper outlined the major projects and areas and suggested the framing used in explaining their existence. This paper does not claim though that mere inclusion into the roadmaps guarantees the projects' successful implementation as demonstrated by many projects which were initially announced but later abandoned (see, for instance, Tashkent Times 2020). While the evaluation of the efficiency and implementation of these projects remains the prospective area of research, this task remains outside of the scope of coverage of current paper.

\section{Energy infrastructure development through cooperation roadmaps}

In all four cases of Russia, China, South Korea, and Japan, there is a profound interest in cooperation with Uzbekistan in the field of energy infrastructure development. This is a natural field of interest given Uzbekistan's underdeveloped resources of natural gas, uranium, and solar/hydropower. However, the process of cooperation and the targeted areas vary by country depending on the expertise/technology possessed and the corporate or governmental interest.

Historically, Russia has been a dominant power with respect to traditional resource development for several reasons. First, the transportation infrastructure that delivers these resources to the end users runs across Russia, and Uzbekistan had no other route for exporting its resources prior to the construction of the China-bound transportation networks. Second, Russia has been and remains the main source of technology, especially in regard to the excavation of mineral resources. Third, Russia is interested in preserving its dominant position in the export of Uzbek resources, although Chinabound alternative channels have been constructed. To a great extent, Russia's sustained interest in preserving its monopoly of the Uzbek market is reflected in the newest roadmaps of cooperation. However, what distinguishes these recent energy-related plans from the previous plans is the bold, controversial decision of the Uzbek government under President Mirziyoyev to seek nuclear technology and construct the first nuclear plant in the CA region using Russian technology (see Table 5). This is potentially a breakthrough development for Uzbekistan, which for a long time has experienced shortages in electricity and natural gas supply because of the preference of the previous government to export natural gas and the underdevelopment of the country's electricity infrastructure. Therefore, among the projects Uzbekistan develops with Russia, nuclear plant construction projects stand out in comparison with the project portfolios in cooperation with other countries. While Russia hopes to use 
Table 5 Examples of projects to be implemented in line with the Uzbek-Russian cooperation roadmap

Nuclear construction plant with Budget of USD 10 billion provided Uz Rosatom

by Russian credits; operation planned in 2030 to provide for $17 \%$ of the energy needs of the country

Development of gas field in
Surkhandarya in cooperation
with Gas Project Development
Central Asia AG and Altmax
Holding

Increase in the capacity of Gazli natural gas collector to 10 billion cubic meters with Forus company
Search and excavation of gas resources and audit of available resources (estimated USD 5.250 million)

Feasibility study of increasing the capacity of natural gas reservoirs; search for additional reserves of natural gas and possibly crude oil (USD 850 million)

Development of the new Djel field with Gazprom

Modernization of the Farkhad hydroelectric power plant in cooperation with Silovye Mashiny, Energomash, and Electrosila

\section{Modernization of the Farkhad hydroelectric power plant in cooperation with Silovye Mashiny, Energomash, and Electrosila}

Construction of the Mullalak hydroelectric power dam (240 MW) and Verhnepskem Dam (200 MW) with Rusgidro

Modernization of the Syrdarya heat-electric station Silovye Mashiny, Energomash, and Electrosila

Development of the plan of modernization, delivery of the equipment, installation, and maintenance of the equipment (to be implemented with a loan of USD 74.2 million from Russian Vnesheconombank)

Development of the plan of modernization, delivery of the equipment, installation, and maintenance of the equipment (to be implemented with a loan of USD 74.2 million from Russian Vnesheconombank)

Development of technical documentation and implementation of the construction of two new plants (implementation by 2021)

The Russian companies are responsible for technical support and equipment delivery/installation, while the
Uzatom state agency (to be established as a subcontractor and exploitation agency for the nuclear plant)

Uzbekneftegaz company

Uzbekneftegaz national company

Uzbekneftegaz national company

Uzbekgidroenergo company Uzbek side provides a loan of USD 177.2 million from Uzpromstroibank (implementation by the end of 2020)
Uzbekgidroenergo company

Uzbekgidroenergo company

Uzbekenergo company

Source: Based on the agreements achieved during the visit of October 18-19, 2018, of the president of Russia to Uzbekistan and the presidential decree on November 3, 2018, PP-3997. Compiled by authors

Uzbekistan to export its nuclear technology and set a precedent for other CA countries seeking nuclear technology, such as Kazakhstan, Uzbekistan regards cooperation with Russia regarding nuclear plant construction as a way to diversify and increase its 
electricity generation capacity, which is crucial for its industrial development. Therefore, Uzbekistan does not regard nuclear plants as just a way to meet its current electricity needs but rather as a way to expand its industrial potential.

As shown above, Uzbekistan employs Russian companies in the construction of nuclear power plants and in the much-needed modernization of existing electricity and hydropower facilities. Many of these facilities were constructed during the time of the Soviet Union, and thus, Russia is in the best position to modernize them. The construction of new hydroelectricity generation plants is also to be conducted by Russian companies because of the expertise these companies have working in Uzbekistan and because of the common understanding of technical language between Russian and local specialists, which represents an advantage of Russian companies when compared with Chinese, South Korean, and Japanese companies. Again, for Uzbekistan, the modernization of these facilities is meant not only to meet the current needs of the country but also to prepare the country for intensified industrialization, which would require a significant amount of newly generated and sustainable energy resources.

The China-related projects of roadmaps of cooperation to some extent resemble those of Russia (see Table 6). They also focus on the excavation and development of new reserves of various energy sources. However, the greatest difference is that many of these projects are conceptualized as a part of the Silk Road projects and are meant to connect Chinese end users with Uzbek suppliers. This is currently a very important task

Table 6 Examples of projects to be implemented in line with the Uzbek-Chinese cooperation roadmap

Implementation of the project on processing coal into olefin and further reprocessing into value-added products at the Shargun and Baisun fields (joint venture with Sinopek and China Energy Investment Company)

Organization of excavation works of hydrocarbons from upstream fields by Sinopec

Organization of the production of modern catalyzers for chemical and oil industries with Sinopec

Credit agreement with the Silk Road Fund for hydrocarbon excavation projects under the guarantee of the government of Uzbekistan for USD 600 million

Organization of the production of modern catalyzers for chemical and oil industries with Sinopec

Credit agreement with the Silk Road Fund for hydrocarbon excavation projects under the guarantee of the government of Uzbekistan for USD 600 million

Attraction of advanced Chinese technologies to process graphite into a value-added product; extraction of samples from Taskazgan field and their conveyance to China; analysis of the needed technologies

Implementation of power and wind energy plant construction in Navoi, Samarkand, and Bukhara for USD 720 million with Liaoning Investment Group
Ministries of Energy, Investments, Energy, Uzbekneftegaz, Uzbekistan railways

Ministries of Energy, Investments, Uzbekneftegaz

Ministries of Energy, Investments, Uzbekneftegaz

Ministries of Energy, Investments, Uzbekneftegaz

Ministries of Energy, Investments, Uzbekneftegaz

Ministries of Energy, Investments, Uzbekneftegaz

State Committee for Geology and Mineral Resources, Local Administration of Bukhara, Uzpromstroymaterialy

Ministries of Energy, Investments

Source: Based on the agreements achieved during the visit of April 24-27, 2019, by the President of Uzbekistan to China and the presidential decree on May 4, 2019, PP-4308 (Also see Decree of the President of the Republic of Uzbekistan 2017). Compiled by authors 
for Uzbekistan given its aim to de-colonize its access to the world markets and avoid over-reliance on the Russian route. The second difference between Chinese projects and Russian projects is that the Chinese projects are almost fully paid for by loans from China-established financial institutions, such as the Asian Bank of Infrastructure and Investments (ABII) and the Silk Road Fund. In this sense, these projects do not necessarily put a financial burden on Uzbekistan in the short run and thus look attractive. However, the long-term perspectives of repaying these loans have not yet been properly discussed and considered. The loan repayment is especially uncertain because Uzbekistan announced in 2019 that it aims to stop supplying natural gas to foreign markets by approximately 2025 and use it instead for domestic consumption and the production of value-added products. In addition, Uzbekistan indicated that it aims to establish a hub for natural gas supplies to regional states, thus favoring regional consumers over Russian and Chinese consumers. Third, the new technology that China offers to Uzbekistan relates to the construction of solar and wind power electricity generation capability that Uzbekistan does not have on its own at present. Given Uzbekistan's abundant solar and wind resources, China-related projects offer a unique technology that can potentially revolutionize Uzbekistan's energy sector.

The cooperation roadmaps with South Korea build heavily on the long history of South Korean companies' participation in the economy of Uzbekistan since the era of the first president of Uzbekistan (as in Table 8). Many of the projects included in the new roadmaps are implemented by companies that have long been established in Uzbekistan (Table 7). In addition, many of these companies do not emphasize the extraction of energy resources for transport to South Korea, which is logistically very challenging. Rather, they attempt to use the abundant resources available in Uzbekistan

Table 7 Examples of projects to be implemented in line with the Uzbek-Korean cooperation roadmap

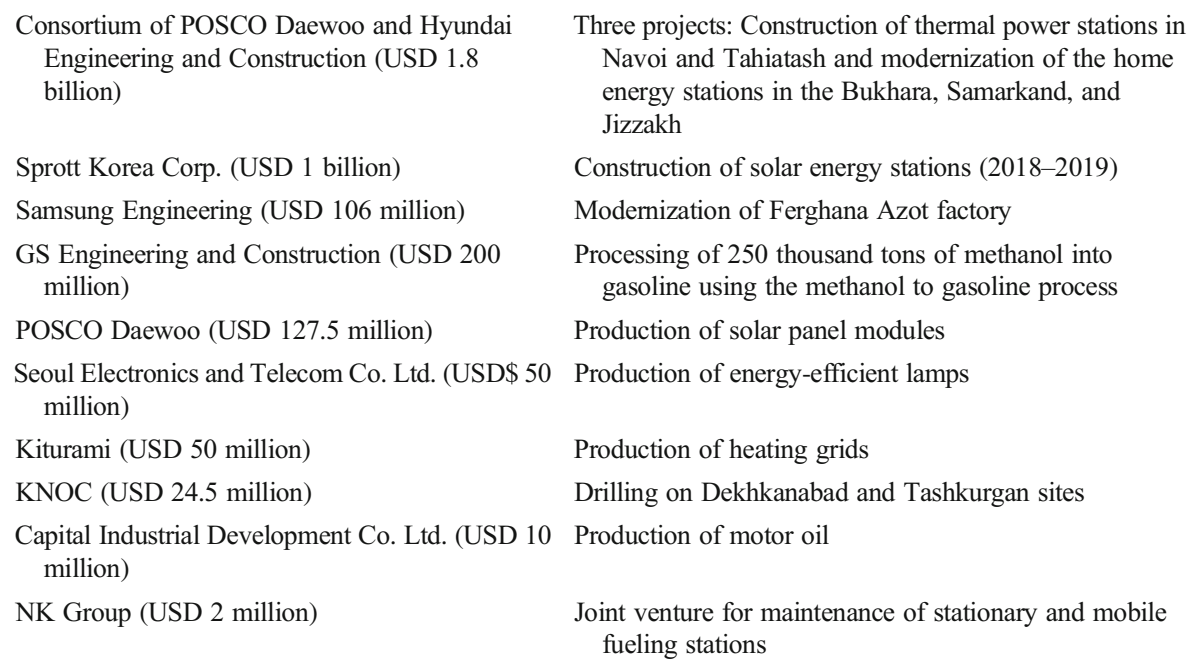

Source: Based on the agreements achieved during the visit of President of the Republic of Korea Moon Jae-in to Uzbekistan on April 29, 2019. Compiled by authors 
Table 8 Examples of projects to be implemented in line with the Uzbek-Japanese cooperation roadmap

\begin{tabular}{|c|c|c|}
\hline $\begin{array}{l}\text { Navoi Thermal Power Station Modernization } \\
\text { Project (Third Gas Combined Cycle Plant) }\end{array}$ & Ministry of Energy & JICA \\
\hline $\begin{array}{l}\text { Navoi Thermal Power Station Modernization } \\
\text { Project (Fourth Gas Combined Cycle Plant) }\end{array}$ & Ministry of Energy & JICA \\
\hline Syrdarya Thermal Power Station construction & Ministry of Energy & Mitsubishi Corp. \\
\hline $\begin{array}{l}\text { Introduction of automation process control } \\
\text { systems of "Uzbekneftegaz" and } \\
\text { "Uzkimesanoat" }\end{array}$ & $\begin{array}{l}\text { Ministry of Energy, } \\
\text { "Uzbekneftegaz" and } \\
\text { "Uzkimesanoat" }\end{array}$ & Yokogawa Corp. \\
\hline $\begin{array}{l}\text { Joint geological study with the Uzbek government } \\
\text { of gold and tungsten resources in Navoi State, } \\
\text { Uzbekistan, for eventual exclusive mining } \\
\text { rights for Japanese companies }\end{array}$ & Goscomgeology & $\begin{array}{l}\text { Japan Oil, Gas and Metals } \\
\text { National Corporation } \\
\text { (JOGMEC) }\end{array}$ \\
\hline $\begin{array}{l}\text { Agreement on the joint exploration of uranium in } \\
\text { Uzbekistan }\end{array}$ & Goscomgeology & Itochu JOGMEC \\
\hline
\end{tabular}

Source: Based on the agreements achieved during the visit of December 17-20, 2019, by the President of Uzbekistan to Japan and the presidential decree on May 4, 2019, PP-4308. Compiled by authors

for the production of value-added products, and this orientation is well received by the government of Uzbekistan, which aims to develop its own export-oriented production of value-added goods instead of exporting raw mineral resources. The majority of the projects mentioned below have such a focus, as shown in the list of representative projects below.

The Japan-related projects with respect to energy resource management mainly reflect the strength of Japanese companies in modernizing existing facilities using the up-to-date Japanese know-how. In this sense, Japan tends to offer Uzbekistan newer and more sustainable technologies than Russia offers. The Japanese government has already participated in the modernization of the Navoi thermal power station by building the second gas combined cycle plant (JICA Navoi thermal power station) (for details of the Japanese engagements in Uzbekistan, see Dadabaev 2016; JICA $2020 \mathrm{a}, \mathrm{b})$. The new roadmaps include the construction of a new gas combined cycle plant. The second area in which Japan has historically shown interest is the area of natural resource exploration, especially regarding resources Japan can use in its own market (JOGMEC 2009). One such resource is uranium, which Japan utilizes in its nuclear plants. The roadmaps include two contracts for deliveries of uranium, one by Marubeni Corporation for USD 480 million and another Itochu Corporation for USD 600 million. Additionally, the Uzbek government formulated a project with the Japan Oil, Gas and Metals National Corporation (JOGMEC) for a joint geological study of gold and tungsten resources in the Navoi region with the possibility of eventual exclusive mining rights for Japanese companies (Global Trade Alert 2019). The third area that benefits Uzbekistan is the security of nuclear power plants. Japan has both positive and negative experiences in this area that it can offer to Uzbekistan. The positive experience relates to Japan's use of a great number of nuclear plants and significant reliance on their secure functioning in providing sustainable energy supplies to its economy. The negative experience relates to several nuclear incidents in Japan, the largest of which occurred in March 2011 and provided a grave but yet indispensable experience for Japan regarding secure nuclear plant exploitation. The government of 
Uzbekistan, as reflected in the cooperation roadmaps, hopes to benefit from such expertise as it builds its own first nuclear plant and its nuclear agency Uzatom.

The Uzbek governments' energy-related roadmaps include 33 documents, with the following projects representing their essence (see Table 8).

As shown by the projects above, Uzbekistan's partners attempt to capitalize on the expertise and experience they have in conducting various projects. In the case of Uzbekistan, however, the major concern of the government is energy capacity development, which would allow additional energy generation in light of the increase in consumption associated with the intensified industrialization of the country. In addition, exploration of the existent resources of Uzbekistan serves as the backbone for its exports and the foreign currency revenues badly needed for purchases of equipment and modernization projects.

\section{Transportation infrastructure construction}

In terms of transportation development infrastructure, not all roadmaps refer to the development of transportation infrastructure in terms of connectivity. The most vocal partner in terms of official rhetoric and roadmaps with respect to constructing and developing the transportation infrastructure in Uzbekistan has been China. This is related to the fact that China's new Silk Road initiative aims to shorten the time spent transporting Chinese goods to foreign markets. In this sense, as described in the third section of this paper, China sees the development of transportation infrastructure as one of the pillars of bilateral cooperation with Uzbekistan. As described in the list of projects included in the roadmaps, the construction of various corridors ranks high on the agenda of cooperation with China, and Uzbekistan fully supports this type of project because it also offers opportunities for Uzbek goods to reach the Chinese market (see Table 9). A good example of this is the construction of railroads from Uzbekistan through Kyrgyzstan to China (for details and challenges of this project, see Dadabaev 2018b). Uzbekistan is a strong supporter of this project. The second type of projects Uzbekistan prioritizes in the cooperation roadmaps with China is establishing a single tariff transportation infrastructure unifying the costs of transportation services. This would allow potential clients to use one tariff for transporting their goods through several states. Additionally, Uzbekistan lobbies for the simplification of transportation and licensing procedures to transport its agricultural produces into China. Deliberation and consultations related to this subject are also included in the roadmaps, as indicated below.

Interestingly, the third type of projects includes the ones that do not necessarily address infrastructure in the territory of Uzbekistan but rather connect the infrastructure of Uzbekistan with that of Afghanistan or seek funding for the construction of Uzbek-Afghan transportation infrastructure (see Table 10). Through this approach, Uzbekistan seeks to achieve several objectives. First, the government of Uzbekistan (and its main national railway company Uzbekistan Temir Yollari) seeks the role of subcontractors for international developmental agencies and organizations in constructing infrastructure for Afghanistan. Uzbekistan already has such experience in northern Afghanistan, and it aims to economically benefit from the construction of such projects. Second, Uzbekistan regards Afghanistan, 
Table 9 Examples of projects to be implemented in line with Uzbek-Chinese cooperation roadmap

\section{Further development of the Uzbekistan-Kyrgyzstan-China corridor}

1. Unification of allowable sizes of the tracks/automobiles on the roads of Kyrgyzstan with other countries and international standards

2. Unification of the processes at border crossings

3. Creation of logistical centers on the Andijan-Osh-Irkeshtam-Kasgar route

4. Creation of more favorable conditions on the route of Linyungan-Irkeshtam-Osh and further towards Europe

5. Negotiations with China regarding discounts for railroad load delivery from eastern ports of the PRC to Kashgar and back for goods from Uzbekistan

Further construction of the railroad from Uzbekistan through Kyrgyzstan to China

Consultations regarding the Mazar-i-Sharif-Kabul-Peshawar railroad construction

Setting of the single tariff for transportation of goods from the Yellow Sea to Central Asia to Europe

Increase in the volume of the agricultural products to be exported to the PRC

\footnotetext{
Kamchik Automobile Tunnel construction $(13.1 \mathrm{~km}$, $2 \times 6.5 \mathrm{~km}$ ) by China Railway Tunnel Group
}

Consultations with all the parties with the participation of Russia; decision regarding the funding

1. Establishment of a working group under the chairmanship of Uzbekistan and with the participation of Chinese specialists

2. Feasibility study of the implementation of the project within the China-Pakistan railroad construction framework

3. Connection of the project to the implementation of the Uzbekistan-Kyrgyzstan-China railroad

4. Drafting of the comprehensive agreement on financing, designing, and constructing the Mazar-i-Sharif-Kabul-Peshawar railroad

Intensification of Uzbek participation in the CAREC program and establishment of a single tariff along the route

Implementation of a sanitary protocol; discussions on receiving permits to increase the exports of cherries and red peppers to the $\mathrm{PRC}$; organization of visits of Chinese experts for inspection of watermelon plantations

Negotiations with China Railway Tunnel Group and organization of a visit to Uzbekistan; preparation of the documentation for loan application to Eximbank
MOFA, Ministries of Transportation, Trade Chamber

Ministries of Transportation, Investments and Uzbek Railways

Ministries of Transportation, Investments, Foreign Affairs, Finance and Uzbek Railways

Ministries of Transportation, Investments and Uzbekistan Railways

State Plants Quarantine Inspection, Ministry of Investments

Ministry of Transportation, Ministry of Investments and Finance

Source: Based on the agreements achieved during the visit of April 24-27, 2019, by the President of Uzbekistan to China and the presidential decree on May 4, 2019, PP-4308. Compiled by authors 
Table 10 Examples of projects to be implemented in line with Uzbek-Chinese cooperation roadmap

\begin{tabular}{|c|c|c|}
\hline $\begin{array}{l}\text { SCO-Afghanistan contact group work } \\
\text { intensification }\end{array}$ & $\begin{array}{l}\text { Working out proposals, multilateral and } \\
\text { bilateral negotiations on the economic } \\
\text { integration of Afghanistan into CA, } \\
\text { peace building in Afghanistan in } \\
\text { collaboration with the PRC, and } \\
\text { implementing projects in education, } \\
\text { trade, energy and transportation }\end{array}$ & $\begin{array}{l}\text { MOFA, Ministries of } \\
\text { Transportation, } \\
\text { Energy }\end{array}$ \\
\hline $\begin{array}{l}\text { Working out "Financial dialogue for } \\
\text { CA and Afghanistan" for attracting } \\
\text { investments to implement } \\
\text { infrastructure development }\end{array}$ & $\begin{array}{l}\text { Developing the concept, consultations } \\
\text { regarding the policy with Afghanistan, } \\
\text { Kazakhstan, Kyrgyzstan, Tajikistan, } \\
\text { and Turkmenistan as well as the ABII, } \\
\text { Silk Road Fund, ABD, and EBRD; } \\
\text { organizing the first meeting of the } \\
\text { Financial Dialogue of CA and } \\
\text { Afghanistan; offering a concrete } \\
\text { proposal especially in the fields of } \\
\text { transportation, logistics and trade } \\
\text { through the China-CA-Afghanistan dia- } \\
\text { logue }\end{array}$ & $\begin{array}{l}\text { MOFA, Ministries of } \\
\text { Transportation, } \\
\text { Energy, Central } \\
\text { Bank }\end{array}$ \\
\hline
\end{tabular}

Source: Based on the agreements achieved during the visit of April 24-27, 2019, by President of Uzbekistan to China and Presidential decree from May 4, 2019, PP-4308. Compiled by authors

along with other CA states, as the primary focus of its policy of economic expansion (for details, see Dadabaev 2020a). Thus, railroad construction into Afghanistan is one goal that Uzbekistan hopes to achieve by connecting its projects with those that China supports in its Belt and Road initiative. Third, in search of integrating Afghanistan into its own infrastructure and opening up the market of Afghanistan for its own transportation services, Uzbekistan seeks to establish a financial dialogue for CA and Afghanistan in which it plays a central role. It also seeks to exploit the opportunities offered by the construction of transportation infrastructure along the Pakistan-China route to fund the Afghanistan-Uzbekistan portion of the railroad, specifically focusing on connecting the Uzbekistan-Mazar-i-Sharif part to Kabul and south Afghanistan. In this sense, Uzbekistan aims to exploit the connectivity offered by the Chinese Road and Belt project to expand its own role as a regional transportation hub. In addition, in December 2018, Uzbekistan's hopes were further boosted by the support of Russia, Kazakhstan, Afghanistan, and Pakistan to create financial consortium for new railway "Mazar-i-Sharif-KabulPeshawar" (see Kerimkhanov 2018).

he Uzbek-Japanese roadmaps suggest that the Japanese participation in transportation infrastructure projects differs from the Chinese one. In this sense, there is no conflict of interest or structural competition in Uzbekistan's vision of China's and Japan's contributions to transportation infrastructure. One aspect emphasized by the Uzbek roadmaps is the Japanese contribution to the modernization of the domestic railway infrastructure by offering Japanese technology for the management of rail communication and the running of railways and airports. In the years following the collapse of the Soviet Union, this sector in Uzbekistan was merged with the management of the national carrier Uzbek Airways, which 
also runs national airports. However, this management structure resulted in corruption, inefficiency, and gross violation of international rules and practices. In early 2019, the government made the decision to de-nationalize airports in an effort to increase their efficiency and increase the attractiveness of the country to visitors. The Uzbek government requested assistance in the modernization of its airports, and the Japanese government has run several phrases of local airport modernization (JICA Priorities in Uzbekistan). In the most recent roadmaps, Uzbekistan launched the initiative of transferring the operation of national airports to foreign companies, and Japanese corporations rank high in the evaluation of the Uzbek government. Through these reforms, Uzbekistan hopes to increase the connectivity of its transportation infrastructure.

\section{Conclusion}

This paper makes three provisional conclusions. First, this paper demonstrated that Uzbekistan is transitioning from an economic model that is tightly controlled by the government towards a model that is more closely related to the developmental state model. In such a model, the government defines its priorities regarding investment and infrastructure development and regarding cooperation with international partners. In this process, the Uzbek developmental state aims to apply its own narrative to energy and infrastructure-related projects from the position of "self" without underplaying the importance of these projects in terms of connectivity and trade promotion. In such a narrative, infrastructure development mainly relates to energy, transport, industrialization, and water and renewables.

Second, this paper claimed that Uzbekistan looks beyond the connectivity rhetoric in its foreign partners' interest in energy and transportation and seeks to capitalize on the related projects to position itself as an industrial and transportation hub for other CA countries and Afghanistan. Uzbekistan is not interested in becoming merely a transit territory for manufactured Chinese goods or an end user of Russian nuclear technology. Additionally, Uzbekistan is not interested in remaining dependent on Russian transportation infrastructure for exporting its energy resources, such as natural gas. Rather, it aims to use the transportation infrastructure to enhance its standing as a logistic hub for goods and technology, which would eventually result in the production of certain industrial goods to be re-exported to Russia, China, Afghanistan, and other countries. For Uzbekistan, these infrastructure initiatives are part of its de-colonization agenda aiming to shift its economy from being resource-based to being based on the export of value-added products.

Third, Uzbekistan attributes various roles to the projects undertaken with its foreign investment partners, with Russia being mainly attributed the role of traditional energy transporter and the newly acquired role of nuclear plant construction partner. Chinarelated projects focus on energy and transportation infrastructure generation as well as local manufacturing. South Korean projects with Uzbekistan focus primarily on medium- and small-scale enterprise cooperation, the processing of local mineral resources into export-ready products, and the modernization of Uzbek governance and urban management. Japan serves largely as a provider of know-how for the optimization of railroad transportation and airports. 


\section{References}

Ahrens J, Hoen HW, Spechler MC (2016) State capitalism in Eurasia: a dual-economy approach to Central Asia. In: Brusis M, Ahrens J, Wessel MS (eds) Politics and legitimacy in post-soviet Eurasia. Palgrave Macmillan, London

Ahrens J, Stark M (2014) 'Emulating East Asian Developmental States? The Institutional Foundations of Economic Transition in Central Asia', Critique Internationale. Revue Comparative de Sciences Sociales, 63(Avril-Juin), 95-110

Bolesta A (2019) From socialism to capitalism with communist characteristics: the building of a post-socialist developmental state in Central Asia. Post-Communist Econ:1-28. https://doi.org/10.1080/14631377. 2019.1694350

Chen X, Fazilov F (2018) Re-centering Central Asia: China's "new great game" in the old Eurasian heartland. Palgrave Commun 4(2018):71. https://doi.org/10.1057/s41599-018-0125-5

Cooley A (2012) Great games, local rules. Oxford University Press, New York

Dadabaev T (2016) One village-one product: the case of JICA's community empowerment project in Kyrgyzstan. In: Dadabaev T (ed) Japan in Central Asia: strategies, initiatives, and neighboring powers. Palgrave Macmillan, New York, pp 69-85

Dadabaev T (2018a) "Silk Road" as foreign policy discourse: the construction of Chinese, Japanese and Korean engagement strategies in Central Asia. J Eurasian Stud 9(1):1-12

Dadabaev T (2018b) Japanese and Chinese infrastructure development strategies in Central Asia. Jpn J Polit Sci 19(3):1-20

Dadabaev T (2018d) The Chinese economic pivot in Central Asia and its implications for post-Karimov reemergence of Uzbekistan. Asian Surv 58(4):747-769

Dadabaev T (2018e) Uzbekistan as central Asian game changer? Uzbekistan's foreign policy construction in the post-Karimov era. Asian J Comparat Politics 4(2):162-175

Dadabaev T (2019a) Chinese, Japanese and Korean in-roads into Central Asia: comparative analysis of the economic cooperation road maps for Uzbekistan. East-West Center, Honolulu/Washington

Dadabaev T (2019b) Transcontinental silk road strategies: comparing policies of China, South Korea and Japan in. Routledge, Uzbekistan

Dadabaev T (2019c) Developmental state and foreign policy in post-Karimov Uzbekistan. In: the SAGE handbook of Asian foreign policy. SAGE, London, pp 893-917

Dadabaev T (2020a) Trump's 'Walk Away' strategy and the future of post-election Afghanistan. Asian Survey (University of California Press) 60(1):213-220. https://doi.org/10.1525/AS.2020.60.1.213

Dadabaev T (2020b) De-securitizing the "Silk Road": Uzbekistan's cooperation agenda with Russia, China, Japan, and South Korea in the post-Karimov era. J Eurasian Stud (accepted, forthcoming). https://doi.org/ $10.1177 / 1879366520943896$

Djalilova N, Esteban M (2018) 2018 'Feasibility study of hybrid wind-solar stand-alone energy systems for remote regions in developing countries: the case of post-soviet Uzbekistan'. Int J Sust Future Human Sec $6(1): 3-14$

Daryo UZ (2017) 'Shavkat Mirziyoev: Uzbekistoga haftasiga hech bomaganda un nafar turist jonatmagan elchi bizga kerak emas [Shavkat Mirziyoev: we do not need ambassadors who do not send even 10 tourists to Uzbekistan]', Daryo.uz, available at https://daryo.uz/k/2017/12/22/shavkatmirziyoyevozbekistonga-haftasiga-hech-bolmaganda-on-nafar-turist-jonatmagan-elchi-bizga-kerakemas/. Accessed 30 Mar 2020

Decree of the President of Uzbekistan (2017) 'O Merah Po Rasshireniyu Vsestorennogo Strategicheskogo Partnerstva Mezhdu Respublikoi Uzbekistan I Kitaiskoi Narodnoi Respublikoi’ [On measures for expanding multidirectional strategic partnership between Republic of Uzbekistan and People's Republic of China], PP-2982, May 19, available at http://www.norma.uz/raznoe/postanovlenie_ prezidenta_respubliki_uzbekistan_ot_19_05_2017_g_pp-2982. Accessed 30 Mar 2020

Decree of the President of the Republic of Uzbekistan (2017) 'O Merakh po Organizatsii Sovremennogo Proizvodstva Detskih Prinadlezhnostei i Igrushek v Gorode Tashkente [On measures for organization of production of children's accessories and toys in the city of Tashkent]', PP-3115, available at lex.uz/pages/ getpage.aspx?lact_id=3257135. Accessed 30 Mar 2020

Dugin A (2007) Geopolitika Post-Moderna: Vremena Novyh Imperii. Ocherki Geopolitiki 21 Veka (Geopolitics of post-modern: the times of new empires. Essays on geopolitics of 21st century), Saint Petersburg, Amfora

Fazendeiro BT (2017) Uzbekistan's defensive self-reliance: Karimov's foreign policy legacy. international affairs 93(2):409-427. https://doi.org/10.1093/ia/iiw062 
Fazendeiro BT (2018) Uzbekistan's foreign policy: the struggle for recognition and self-reliance under Karimov. Routledge, Oxford

Fazendeiro BT (2015) Uzbekistan's "spirit" of self-reliance and the logic of appropriateness: TAPOich and interaction with Russia. Centr Asian Survey 34(4):484-498. https://doi.org/10.1080/02634937.2015. 1114780

Freeman CP (2018) New strategies for an old rivalry? China-Russia relations in Central Asia after the energy boom. Pac Rev 31:635-654. https://doi.org/10.1080/09512748.2017.1398775

Global Trade Alert (2019) JOGMEC gold and tungsten resource survey for Japanese mining in Uzbekistan. Global Trade Alert https:/www.globaltradealert.org/state-act/43072/japan-jogmec-gold-and-tungstenresource-survey-for-japanese-mining-in-uzbekistan. Accessed 15 Feb 2020

Islamov B (2019) Post Karimov's foreign economic reforms in Uzbekistan and their first results. Chiiki Keizai Keiei Netwa-ku Kenkyu Senta Nenpo, University of Hokkaido 8:80-82. https://eprints.lib.hokudai.ac.jp/ dspace/bitstream/2115/73675/1/095-2186-9359-8.pdf. Accessed 30 Mar 2020

Japan Oil, Gas and Metals National Corporation (JOGMEC) (2009) JOGMEC to launch the first uranium joint exploration in Uzbekistan. JOGMEC. http://www.jogmec.go.jp/english/news/release/release0023.html Accessed 15 Feb 2020

Johnson C (1982) MITI and the Japanese miracle: the growth of industrial policy, 1925-75, Stanford

Johnson C (1999) 'The developmental state: odyssey of a concept', in Meredith Woo-Cumings (ed.), the developmental state, Ithaca and London, pp. 32-60

JICA (2020a) JICA priorities in Uzbekistan. JICA. https:/www.jica.go.jp/uzbekistan/english/activities/ priorities_01.html. Accessed 15 Feb 2020

JICA (2020b) Navoi thermal power station modernization project (second gas combined cycle plant). JICA.https://www.jica.go.jp/english/our_work/social_environmental/id/asia/central/uzbekistan/ c8h0vm000090rx3e.html. Accessed 15 Feb 2020

Karimov I (1992) Uzbekistan na Poroge XXI Veka: Ugrozy Bezopasnosti, Uslovia i Garanatii Progressa [Uzbekistan on the threshold of the 21st century: challenges to its security, conditions and guarantees of progress]. Drofa, Moscow

Kerimkhanov A (2018) 'Russia, Uzbekistan, Kazakhstan, Afghanistan, Pakistan to create financial consortium for new railway', Azernews, 7 December 2018. https://www.azernews.az/region/142250.html. Accessed 30 Mar 2020

Khodzhaev A (2007) Kitajskij Faktor v Tsentral'noi Azii [Chinese Factor in Central Asia]. Fan, Tashkent

Lane D (2005) Emerging varieties of capitalism in former state socialist societies. Compet Chang 9(3):227247

Lane D (2007) Post-state socialism: a diversity of capitalisms? In: Lane D, Myant M (eds) Varieties of capitalism in post-communist countries. Palgrave Macmillan, New York, pp 13-39

Libman A (2008) "Government-business relations in post-soviet space: the case of Central Asia," MPRA paper 11874. University Library of Munich, Germany

Megoran N, Sharipova S (2013) Central Asia in international relations: the legacies of Halford Mackinder. Hurst and Co, London

OECD (2019) Green finance and investment sustainable infrastructure for low-carbon development in Central Asia and the Caucasus hotspot analysis and needs assessment: hotspot analysis and needs assessment. OECD Publishing. https://www.oecd-ilibrary.org/sites/5fd38a3d-en/index.html?itemId=/content/ component $/ 5 \mathrm{fd} 38 \mathrm{a} 3 \mathrm{~d}$-en\&mimeType=text/html\#tablegrp-d1e32483. Accessed $30 \mathrm{Mar} 2020$

President's Office (2019) Poryadok litsenzirovanij I vydachi razreshenij budet kardinalno usoveshenstvan (the order of licensing and granting permissions will be cardinally improved). https://president.uz/ru/lists/view/ 3360. Accessed 17 Feb 2020

President's Office (2020) Poryadok litsenzirovanij I vydachi razreshenij budet kardinalno usoveshenstvan (the order of licensing and granting permissions will be cardinally improved). President's Office. https:// president.uz/ru/lists/view/3360. Accessed 17 Feb 2020

Pikalov A (2014) Uzbekistan between the great powers: a balancing act or a multi-vectorial approach? Centr Asian Survey 33(3):297-311

Popov V (2007) Shock therapy versus gradualism reconsidered: lessons from transition economies after 15 years of reforms. Comp Econ Stud 49(1):1-31

Stark M (2012) 'The emergence of developmental states from a new institutionalist perspective: a comparative analysis of East Asia and Central Asia'. Emerging markets studies 2. Peter Lang, Frankfurt/Main

Stark M, Ahrens J (2012) "Economic reform and institutional change in Central Asia: towards a new model of the developmental state?," PFH Forschungspapiere/Research Papers 2012/05. PFH Private University of Applied Sciences, Göttingen 
Spechler DR, Spechler MC (2010) The foreign policy of Uzbekistan: sources, objectives and outcomes: 19912009. Centr Asian Survey 29(2):159-170

Spechler MC (2000) Uzbekistan: the silk road to nowhere? Contemp Econ Policy, Western Economic Association International 18(3):295-303

Swanstrom N (2005) China and Central Asia: a new great game or traditional vassal relations? J Contemp China 14(45):569-584

Tashkent Times (2020) "Samarkand solar power plant project suspended", June 25, 2018, https:// tashkenttimes.uz/economy/2528-samarkand-solar-power-plant-project-suspended. Accessed 30 Mar 2020

TCA (2017) Uzbekistan estimates the effect of import substitution at \$2 billion in 2016. The Times of Central Asia. February 14. www.timesca.com/index.php/news/17679-uzbekistan-estimates-the-effect-of-importsubstitution-at-2-billion-in-2016

Thompson MR (2017) From Japan's 'Prussian path' to China's 'Singapore model': learning authoritarian developmentalism. In: Carroll T, Jarvis DSL (eds) Asia after developmental state: disembedding autonomy. Cambridge University Press, Cambridge, pp 148-173

The State Committee of the Republic of Uzbekistan on National Statistics (2020) Analysis of the demography of enterprises and organizations of the republic of Uzbekistan. https://stat.uz/en/press-center/newscommittee/8465-analysis-of-the-demography-of-enterprises-and-organizations-of-the-republic-ofuzbekistan-01-02-2020. Accessed 17 Feb 2020

Strategy Center (2017) UZINFO action strategy on five priority directions for the development of the Republic of Uzbekistan 2017-2021. http://strategy.gov.uz/ru/lists/docview/96/. Accessed 17 Feb 2020

UZ.A (2018) 'Effektivnaya Venshnyaya Politika: Vazhneishee Uslovie Uspeshnoy Realizatsii Vneshnei Politiki [Effective foreign policy: the most important condition of the successful foreign policy]', Uza. uz, January 12, 2018, available at: http://uza.uz/ru/politics/effektivnaya-vneshnyaya-politikavazhneysheeuslovie-uspeshn-12-01-2018?ELEMENT_CODE=effektivnaya-vneshnyaya-politikavazhneysheeuslovie-uspeshn-12-01-2018\&SECTION_CŌDE=politics\&print=Y. Accessed 30 Mar 2020

Publisher's note Springer Nature remains neutral with regard to jurisdictional claims in published maps and institutional affiliations. 